\title{
The Integration of Education for Sustainable Development (ESD) in Design and Technology Subject: Through Teacher's Perspective
}

\author{
Rabbiatul Natrah Rosman', Muhd Khaizer Omar², \\ Zulhazmi Zahari ${ }^{2}$ \\ ${ }^{1,2}$ Faculty of Educational Studies, Universiti Putra Malaysia, 43400, Serdang, \\ Selangor Darul Ehsan, Malaysia. \\ 'natrahrosman2803@gmail.com
}

Received: 24 October 2019; Accepted: 16 November 2019; Published: 29 November 2019

\begin{abstract}
The revolution and development of technology have influenced the relationship among people, society, environment, and socio-economy. This issue plays a crucial role in prospering the quality of future grassroots of the nation on the term of values, attitudes, and moral development. Education is a tool that thrives and imparts value-based education, starting from early education. Therefore, to upbringing the aforementioned mission, we employ a phenomenological study to explore the perception and opinion among Design and Technology (DNT) teachers in embedding Education for Sustainable Development (ESD) elements among primary school students. This study focuses on the teacher's pedagogical approach in the classroom contexts and teachers' readiness in the implementation of ESD, comprises of three main elements: environment, social, and economical. The formulated research question for this study is what teachers' views are and how they perceive ESD as part of the subject. Qualitative research was conducted to illustrate the perception and understanding of ESD elements in DNT subjects. Selected participants are among the Head of DNT Panels and at the same time, teach DNT as their major subject. The data were collected using semi-structured interviews. Informants' views and feedback were derived and transcribed using Nvivo software. The theme emerged from the constant comparative analysis were triangulated with secondary data; for example, field observation, memo, journals, and teacher's lesson plan. Analysis of the data indicated that student-centered learning as the theme implemented by most participants to impart ESD through student's learning activities. Education is the optimal mechanism to disseminate ESD and encouraging learners in moral values.
\end{abstract}

Keywords: Education for Sustainable Development, Design, and Technology, Pedagogical Approach Teacher's readiness, Value-Based Education

\section{INTRODUCTION}

Despite the world's rapid growth, UNESCO has set priorities on assuring quality living and encouraging the society to be equitable and observant towards the surroundings, along with fostering awareness on the ecosystem. Throughout history, the pursuit of a well-balanced life has been debated and became primary in the global conference's dialogues. Peace, freedom, development, and environment was the initial preferences to set as the key themes of life (Wolff, Sjöblom, Hofman-Bergholm, \& Palmberg, 2017). As regards to the effort on achieving preferable environment and development, The United Nations Conference on Environment and Development (UNCED) held in 1992, appointed the principles of Agenda 21, which issued conservation on forests, an international agreement on climate change and biodiversity. Ten years later, Sustainable Development (SD) was declared at the World Summit on Sustainable Development (WSSD) in Johannesburg, South Africa, with the assertion of making SD as a concept and goal in the mission of creating a better global environment (UNESCO education strategy 2014-2021; 2014, n.d.)

The concept of ESD also encourages people to be sensible of their actions on improving living and lifestyles (Watanabe, 2015). Education is essential to support the community to learn in a more structured technique, acquire knowledge, and emphasize the importance of achieving well-balanced life (Watanabe, 2015). The idea of ESD indicated by UNESCO is likely to reorient the education system, 
fundamental structure, teaching, and learning (Watanabe, 2015). The general aim of ESD was integrating the principles and practices of sustainable development into all aspects of education and learning, encouraging changes in knowledge, values, and attitude in the vision of enabling a more sustainable and just society for all (UNESCO, 2017, p.7).

The fundamental concept of ESD is to promote environmental conservation, social growth, and economic sustainability (Beka \& Ciani, 2015). The emerging of ESD as a new approach is known to discourse sustainable development goals through education organization (Kalsoom, 2019). It is also stated that to attain positive values and sustainable qualities among the nation, educationalist should devise a multidisciplinary and effective practice besides learning the values through reading materials and examinations (Washington, 2018). ESD also is defined as a transformative learning process that equips students, teachers, and school systems with knowledge and ways of thinking (Chinedu, WanMohamed, \& Ogbonnia, 2018) as well as fostering the students to develop knowledge and skills, to be more observant and compassionate with their ambience. ESD elements should be applied in the teaching approach to transmit knowledge and impart awareness towards sustainable development (Bertschy, Künzli, \& Lehmann, 2013). According to (Bertschy et al., 2013), ESD is an interrelation element and as a learning objective to encourage people, specifically among students to implement sustainable values.

Regardless of its importance in promoting moral values, responsibilities, and awareness, research has emerged with the result which ESD has been given less attention in the curriculum. Teachers tend to focus on environmental education rather than integrate social and economic elements in their teachings (Cebrián \& Junyent, 2015). Education is the essential element in preparing a better community and citizens towards a well-developed environmental, societal, and economic future. However, there are less significant ESD researches involving schools in Malaysia (Yean, 2014). ESD is commonly related to Environmental Science subject and has not been exposed as a subject's topic at school (Hanifah Mahat \& Shaharuddin Ahmad, 2014).

According to G. de Haan et al., (2010), ESD is a crucial element to equip students with quality education, in which the values in ESD are related and relevant in today's challenges towards a sustainable future. It leads to significant and purposeful teaching approaches, along with an active learning process. Other studies have considered that teacher's mastery in the pedagogical approach and practice will influence students' learning process (Pipere, 2015). A comparative study by Pipere (2015) discovered that teaching ESD needs an interdisciplinary approach in providing knowledge, values, and skills among students even though there might have complexity in cultivating the values which require teachers to foster awareness in a broader view of the environment, social and economy. Beka and Ciani (2015) also emphasized that the relationship between pedagogical approach and ESD are essential to enforce critical thinking, persistent knowledge acquisition and to support the transformation of preferred society (Watanabe, 2015).

ESD should encourage teachers to diversify a pedagogical approach that is not only focused on cognitive knowledge (Shohel \& Howes, 2011). Teachers who are compassionate and committed will apply integrative elements to support student's learning process as well as reflecting their sustainable values (Howard, 2012). A research conducted by Gisela and Junyent (2015) indicated that the teaching preference for ESD is only through science education and environmental knowledge. Teachers have given less attention to the environment, society, or economic issues to inquire more about students' perception of what happened in their ambience. A comparative study by Watanabe (2015) found that teachers had mistaken the perception towards ESD by assuming that ESD is nature and environmental education. According to Hasslöf, Ekborg, \& Malmberg (2014), the teacher should allow students to express their opinion and perspective on global issues that can relate to the environment, social, and economic aspects. Students' participation in sharing their views will encourage critical thinking along with the insight of responsibility. UNESCO also emphasizes that these elements as one of the resources that teachers could apply in pedagogical approaches throughout the student's learning process specifically to impart values that develop to a better character student (Nadaraj, 2014). Hence, Teachers' proficiency to deliberate ESD elements is crucial in order to instil awareness among the students (Chinedu et al., 2018). 
The purpose of this study is to explore the teacher's pedagogical approach to integrate ESD in Design and Technology subject (DNT). Therefore, a qualitative approach has been conducted to inquire teacher's perspective and views to answer proposed research questions which aim to delve into teacher's readiness and experience as well as the teaching strategies being practiced in embedding ESD specifically to impart moral values among primary school students.

\section{METHODOLOGY}

\section{Research Method}

Interpretivism research philosophy is appointed to support the data collection, which focuses on small sample size as this study will go in-depth of teachers' understanding and perception in ESD pedagogical. Siti Uzairah (2017) reviewed, interpretivism is when the reality formed through selfexperiences towards the environment and community. Interpretivism also is parallel with learning theory, in which knowledge is developed by observation and understanding the surrounds. Along with the research philosophy, the nested approach is referred to as the research framework to conduct the study. Qualitative research encompassed four designs and structures that are commonly used (Prashant, 2013). Coincide with this study; the phenomenology approach will highlight teachers' experience in teaching ESD, as well as them to explore perspectives and views regarding the pedagogical approach that related to teaching ESD. The phenomenology approach is the most suitable method for the researcher to conduct this study. As eloquently stated by Kalsoom (2017), that this approach would increase understanding, create awareness, and interpret a situation or a phenomenon by informants' explanation.

\section{Population and sample}

The target population of this study is graduated teachers in Technical and Vocational Education (TVE) course, teaching Design and Technology (DNT) subject in primary school. The six participants also are among the Head of DNT panels and teaching DNT as the major subject. In this study, the researcher is focusing more on teachers' experience teaching DNT subject with the ESD elements integrated into their teaching practices. As informants, the selected teachers are supposed to have the ability to describe their approaches throughout students' learning activities as well as their views on cultivating ESD in the classroom.

\section{Instrumentation}

Merriam \& Grenier (2019) Described the qualitative research design as an inductive approach which does not necessitate research findings to approve assumptions or hypothesis. This approach also defined as the "bottom-up" approach, where it constructs theories through the researcher's observation and inductive reasoning. Concerning this study, the researcher conducted a semi-structured interview among selected teachers as the informer. As described by Flick (2018), the quality of qualitative research will be strengthened by combining different approaches of collecting data, which is called triangulation. Purposely to increase the validity of research findings as well as to achieve a verified result (Creswell \& Poth, 2017). The interview was conducted in Bahasa Melayu to ensure all questions are comprehensible and interpreted precisely by the informants. This will help the informant expresses their view and converse in a more comfortable feeling. Communicating in a preferred language creates a permissive ambiance between the researcher and the informant (Berger, 2018). The transcribed interview is translated into English in data analysis and further chapters. Detailed information of the participants for this interview shown in Table 1. 
Table 1. Summary of the participants

\begin{tabular}{|c|c|c|c|c|c|c|}
\hline Participant & $\mathbf{A}$ & B & $\mathbf{C}$ & D & $\mathbf{E}$ & $\mathbf{F}$ \\
\hline Gender & Male & Male & Male & Female & Female & Female \\
\hline $\begin{array}{c}\text { Teaching } \\
\text { experience }\end{array}$ & 10 years & 9 years & 9 years & 9 years & 9 years & 10 years \\
\hline $\begin{array}{c}\text { Teaching } \\
\text { period/ } \\
\text { week }\end{array}$ & $24 / 720 \mathrm{mins}$ & $20 / 600 \mathrm{mins}$ & $24 / 720 \mathrm{mins}$ & $16 / 480 \mathrm{mins}$ & $18 / 540 \mathrm{mins}$ & $20 / 600 \mathrm{~min}$ \\
\hline $\begin{array}{c}\text { School } \\
\text { Location }\end{array}$ & $\begin{array}{l}\text { Ipoh, } \\
\text { Perak }\end{array}$ & Putrajaya & $\begin{array}{l}\text { Kulim, } \\
\text { Kedah }\end{array}$ & $\begin{array}{l}\text { Pulau } \\
\text { Pinang }\end{array}$ & $\begin{array}{l}\text { Johor Bahru, } \\
\text { Johor }\end{array}$ & Cyberjaya \\
\hline $\begin{array}{l}\text { Graduated } \\
\text { from }\end{array}$ & $\begin{array}{l}\text { Bachelor of } \\
\text { Vocational } \\
\text { Engineering } \\
\text { Education }\end{array}$ & $\begin{array}{l}\text { Bachelor of } \\
\text { Vocational } \\
\text { Engineering } \\
\text { Education }\end{array}$ & $\begin{array}{l}\text { Bachelor of } \\
\text { Vocational } \\
\text { Engineering } \\
\text { Education }\end{array}$ & $\begin{array}{c}\text { Bachelor of } \\
\text { Vocational } \\
\text { Engineering } \\
\text { Education }\end{array}$ & $\begin{array}{l}\text { Bachelor of } \\
\text { Vocational } \\
\text { Engineering } \\
\text { Education }\end{array}$ & $\begin{array}{c}\text { Bachelor's } \\
\text { Degree } \\
\text { Industrial } \\
\text { Electronic } \\
\text { Engineering }\end{array}$ \\
\hline Position & \multicolumn{6}{|c|}{ Head of DNT panels } \\
\hline
\end{tabular}

\section{RESULTS AND DISCUSSION}

The following illustrates how the themes are organized to relate the research question. Based on findings through the interviews, three themes emerged from the informants' answers, which corresponds to the focus of this study.

\section{Theme One: Contents Knowledge}

\section{Awareness}

All participants mentioned the importance of ESD to promote students' awareness and their contribution to maintaining and improving life towards a better future generation. One of the informants believes that formal education is essential to provide students with knowledge that attributes to global issues such as environmental deteriorate, which requires actions to prevent more destruction on nature and animals' extinction. Most informants have given environmental issues as the subject of their ideas and views, as this example is well-known among primary school students.

\section{Moral Values}

Also obtained through the data analysis is about embedding moral values and ethics. These integrated elements are intended to promote virtuous characteristics through the subject and implement them beyond the classroom. Most of the participants are confident that ESD will enhance the school's curriculum in terms of creating a more responsible generation. Informant $\mathrm{E}$ chooses to highlight the poverty problem happened due to war. The teacher believes that pointing out war as one of the examples could relate to ESD elements.

\section{Improvement}

All participants agreed that ESD as an improvement to the previous curriculum syllabus, which tends to concentrate on certain core subjects for examinations. Informant D also suggests that ESD should be emphasized in every topic so that students will reflect their actions, the impact, and consequences may cause by human activities towards the environment, society, and economy. Another informant believes that the integration of ESD elements into DNT subject as the key for teachers to prepare better teaching and learning activities in the classroom as well as fostering high-principled individuals among the students, even though that this could not be measured by grades and performance in the examination. 


\section{Theme Two: Readiness}

\section{Creativity}

Three participants have emphasized creativity as one of the pivotal aspects of embedding ESD into DNT subject. Creative teachers will always find new methods and compassionate in their teachings to impart knowledge, generate learners' ideas, and encourage an active learning ambiance. With creativity, the teacher will be able to describe a scenario through art by sketching a picture or display a video of any current news related to global issues to stimulate ideas and discussion. A participant had shared her views about creativity in the teaching and learning process by illustrating a recycle logo as introductions before she starts teaching project design topics, which relates to environmental conservation. Another participant pointed out that teacher's creativity in supporting learners' idea and knowledge would motivate and encourage students to create products that have a commercial value which inspires students on entrepreneurship skills, economic relevance for the future.

\section{Resources}

The interview revealed that regardless of courses held by PPD, JPN, and KPM, with ofttimes national curriculum revamp, teachers had given insufficient professional development training specifically about ESD. Teachers are expected to search for their teaching materials and generate their knowledge about ESD contents through the internet. Five of the informants conceded that they did not receive the ESD Teachings and Guidebook or Buku Panduan Pelaksanaan Kelestarian Global even though the book should be distributed across all schools in Malaysia, the only e-book version is available as the official and standard reference. Informant B does have the book since he is teaching in Putrajaya. Most informants choose to integrate ESD through their prior knowledge in global issues and self-experiences about the environmental, social, and economic contexts. Over the interviews, the researcher has discovered that common examples used by teachers are recycling wastes, nature preservation, pollution, and climate change. In social contexts, all informants agreed that teachers should promote unity among the students, respect each other, encourage team cooperation, as well as be more tolerant among peers. Embedding economic elements in DNT topic is quite challenging for teachers due to conceptual ambiguity in educating the learners with economic aspects. Based on the participants' prior knowledge, economy elements in ESD is referring to how learners can earn profit through what they have created. Nevertheless, this viewpoint is not as mentioned in ESD Teachings and Guidebook, which indicates the economic element in broader aspects such as tourism, advanced technologies, currency exchange, world trade, and global economic growth (KPM,2016).

\section{Passion}

Throughout the interview sessions, informants showed that they are motivated to impart ESD in DNT subject with support from the Education Ministry in providing sufficient learning materials for teachers. Informants conceived that integrating ESD elements is essential and is capable of disseminating the importance among the learners. Two of the participants believe that readiness is associated with a teacher's passion. Well supported with relevant materials for teaching and learning process will elevate teacher's motivation as well their readiness to perceive ESD as new integrated elements in DNT subject. Also revealed by the informants, they are keen to be the agent of changes in the education system, as our country is revolutionizing towards globalization. Teachers should be given adequate training and knowledge of ESD since these elements are still unfamiliar in primary school education. Nakata (2011) found similar ideas about being passionate in teachings, which reviewed that teachers' lack of interest in the new curriculum or changes might occur due to the insufficiency of professional development training. 


\section{Theme Three: Student-Centered Learning}

\section{Critical Thinking}

Through the whole interview sessions, participants perpetually mention giving opportunities to the students to express their thoughts about any of the ESD elements based on their knowledge or selfdiscovery, which related to the discussion topic and project. As teacher F remarks, she encourages students to reflect on their daily activities and share their insight on ways to prevent haze or air pollution, which relates to the current situation that happened in Malaysia. As underlined by Hasslöf \& Malmberg (2015), encouraging learners on environmental perspectives will develop their sense of responsibility towards the ecosystem, and the teacher's role is to develop the perspectives along with creating possible meaning concerning ESD elements. According to participant A, it is essential to give freedom for the students to articulate their interpretations about things that happened around them as well as guiding them to emphasize their ideas in proper words and a decent way to avoid misunderstanding. Especially about religion, race, and culture in our multi-racial country. Critical thinking is also affiliated with activities that construct student's rationale through conceptualizing, questioning, finding solutions, and explore new knowledge (Håkansson, Kronlid, \& Östman, 2017).

\section{Collaborative Learning}

Besides critical thinking, most informants agreed that embedding ESD elements in DNT subject would be more exciting and compelling through teamwork and practical activities, in which learners can work together in a team, sharing ideas and learn to respect others as well as achieving the outcomes. Informant $\mathrm{C}$ implied that students acquired their own learning experience as well as fostering values and insight by communicating with teammates to find ways to solve a problem or doing a project. As interpreted by the informants, being able to adapt in a group and accomplish a task together is relevance to the collaborative learning concept (Hensley, 2017).

\section{CONCLUSION}

Implementing values through ESD elements does open up ways for teachers to link teaching strategies into the concept of sustainability suited to primary school students thinking level. It is undeniable that the relationship between ESD and moral values is complied with values education to foster the learners with a sense of responsibility, to be more attentive, and to appreciate the surroundings. ESD consisted of environmental, social, and economic elements, which complement the students' learning process as well as directing the teachers to create a more interactive learning ambience. Teaching about sustainable development encompasses instilling public awareness among the students, encouraging learner's interpersonal through activities in the classroom to enrich understanding about ESD while facilitating the students with knowledge and skills. Therefore, teachers need to consider expanding their knowledge about ESD and acquire more on pedagogy context. Being an educator, and the agent of change required teachers to be committed and ready enough to deliver ESD elements effectively. Hence, teaching the children about responsibilities and cultivating conscience should begin from school as formal education provides suitable and appropriate materials for learners to develop their knowledge. 


\section{REFERENCES}

Abdulrazak, S. R., \& Ahmad, F. Sh. (2014). Sustainable Development: A Malaysian perspective. Procedia Social and Behavioral Sciences, 164, 237-241. https://doi.org/10.1016/j.sbspro.2014.11.072

Beka, A., \& Ciani, A. (2015). Promoting Education for Sustainable Development at the University of Prishtina, Kosovo. World Sustainability Series, 139-151.

Berger, A. A. (2018). Media and Communication Research Methods: An Introduction to Qualitative and Quantitative Approaches. Newbury Park, California: SAGE Publications

Bertschy, F., Künzli, C., \& Lehmann, M. (2013). Teachers' competencies for the implementation of educational offers in the field of Education for Sustainable Development. Sustainability, 5(12), 5067-5080. https://doi.org/10.3390/su5125067

Boeve-de Pauw, J., Gericke, N., Olsson, D., \& Berglund, T. (2015). The effectiveness of Education for Sustainable Development. Sustainability,7, 15693-15717. https://doi.org/10.3390/su71115693

Cebrián, G., \& Junyent, M. (2015). Competencies in Education for Sustainable Development: Exploring the student teachers' views. Sustainability, 7(3), 2768-2786. https://doi.org/10.3390/su7032768

Chinedu, C. C., Wan-Mohamed, W. A., \& Ogbonnia, \& A. A. (2018). A systematic review on Education for Sustainable Development: enhancing TVE teacher training programme. Journal of Technical Education and Training, 10(1). Retrieved from http://penerbit.uthm.edu.my/ojs/index.php/JTET/article/view/1678

Creswell, J. W., \& Poth, C. N. (2017). Qualitative Inquiry and Research Design: Choosing Among Five Approaches. Newbury Park, California: SAGE Publications.

Flick, U. (2018). An Introduction to Qualitative Research. Newbury Park, California: SAGE Publications.

Hanifah Mahat, and Shaharuddin Ahmad, and Mohamad Suhaily Yusri Che Ngah, and Noraziah Ali, (2014) Pendidikan pembangunan lestari - hubungan kesedaran antara ibu bapa dengan pelajar. Geografia : Malaysian Journal of Society and Space, 10 (5). pp. 71-84. ISSN 2180-2491

Hasslöf, H.(2015). The educational challenge in "Education for sustainable development": Qualification, social change and the political. Retrieved from http://public.eblib.com/choice/publicfullrecord.aspx?p=3328183

Hensley, N. (2017). Approaches for education for sustainable development (ESD) in Kesennuma, Japan. A qualitative case study of continuous challenges faced by educators pursuing sustainability in their teaching. Master's Degree Studies in International and Comparative Education No. 45, Stockholm University

Johnson, D. W., \& Johnson, R. T. (2014). Cooperative Learning in 21st Century. Anales de Psicología, 30(3), 841-851. https://doi.org/10.6018/analesps.30.3.201241

Kalsoom, Q. (2019). ESD Literacy-Based Model For Preservice Elementary Teachers: A Focus On Critical And Environmental Consciousness And Effective Teacher Development.(Doctoral dissertation). Lahore College for Women University, Lahore, Pakistan.

Kalsoom, Q., \& Khanam, A. (2017). Inquiry into sustainability issues by preservice teachers: A pedagogy to enhance sustainability consciousness. Journal of Cleaner Production, 164, 1301-1311. https://doi.org/10.1016/j.jclepro.2017.07.047

Lozano, R., Merrill, M. Y., Sammalisto, K., Ceulemans, K., \& Lozano, F. J. (2017). Connecting competences and pedagogical approaches for sustainable development in higher education: A literature review and framework proposal. Sustainability, 9(10), 1889. https://doi.org/10.3390/su9101889

Merriam, S. B., \& Grenier, R. S. (2019). Qualitative Research in Practice: Examples for Discussion and Analysis. Hoboken, New Jersey: John Wiley \& Sons.

Nadaraj, S. (2014). Assessing students socialization processes through hidden curriculum in schools. Asian Journal of Assessment in Teaching and Learning, 4, 1-18.

Nagata, Y. (2017). A critical review of Education for Sustainable Development (ESD) in Japan: Beyond the practice of pouring new wine into old bottles. Educational Studies in Japan, 11, 29-41. https://doi.org/10.7571/esjkyoiku.11.29

Nasibulina, A. (2015). Education for Sustainable Development and Environmental Ethics. Procedia - Social and Behavioral Sciences, 214, 1077-1082. https://doi.org/10.1016/j.sbspro.2015.11.708

Pipere, A. (2015). Education for Sustainable Development Research from the Researchers' Point of View. Journal of Education for Sustainable Development, 6(2), 313-326. doi:10.1177/0973408212475268

Sterling, S. (2016). A commentary on Education and Sustainable Development goals. Journal of Education for Sustainable Development, 10 (2), 208-213. https://doi.org/10.1177/0973408216661886

UNESCO (Ed.). (2005). Rethinking education: Towards a global common good? Paris: UNESCO Publishing.

Warren, A. E., Archambault, L. M., \& Foley, R. W. (2014). Sustainability education framework for teachers: Developing sustainability literacy through futures, values, systems, and strategic thinking. Journal of Sustainability Education 6 (14). Retrieved from http://www.susted.com 
The Integration of Education for Sustainable Development (ESD) in Design and Technology Subject: Through

Teacher's Perspective

Watanabe, R. (2015). Implementation of Education for Sustainable Development (ESD) in Japan: A qualitative case study of formal education in Kesennuma City. Stockholm University, Stockholm, Sweeden. Retrieved from http://urn.kb.se/resolve?urn=urn:nbn:se:su:diva-118868

Wolff, L.-A., Sjöblom, P., Hofman-Bergholm, M., \& Palmberg, I. (2017). High Performance education fails in sustainability? -A reflection on Finnish primary teacher education. Education Sciences, 7(1), 32. https://doi.org/10.3390/educsci7010032

Yean, A. S. (2014). Education for Sustainable Development in Malaysia's National Curriculum reformation: A Theoretical exploration. Journal of International and Comparative Education (JICE), 199-212. https://doi.org/10.14425/00.73.61 